\title{
Genetic Variability, Heritability and Genetic Advance in Carrot (Daucus carota var. sativa L.)
}

\section{Suresh Kumar Teli*, R.A. Kaushik, K.D. Ameta, Vikram Kumar Kapuriya, Dalulal Mali and Lokesh Kumar Teli}

\author{
Department of Horticulture, Rajasthan College of Agriculture, \\ MPUA\&T, Udaipur (Rajasthan) 313001, India \\ *Corresponding author
}

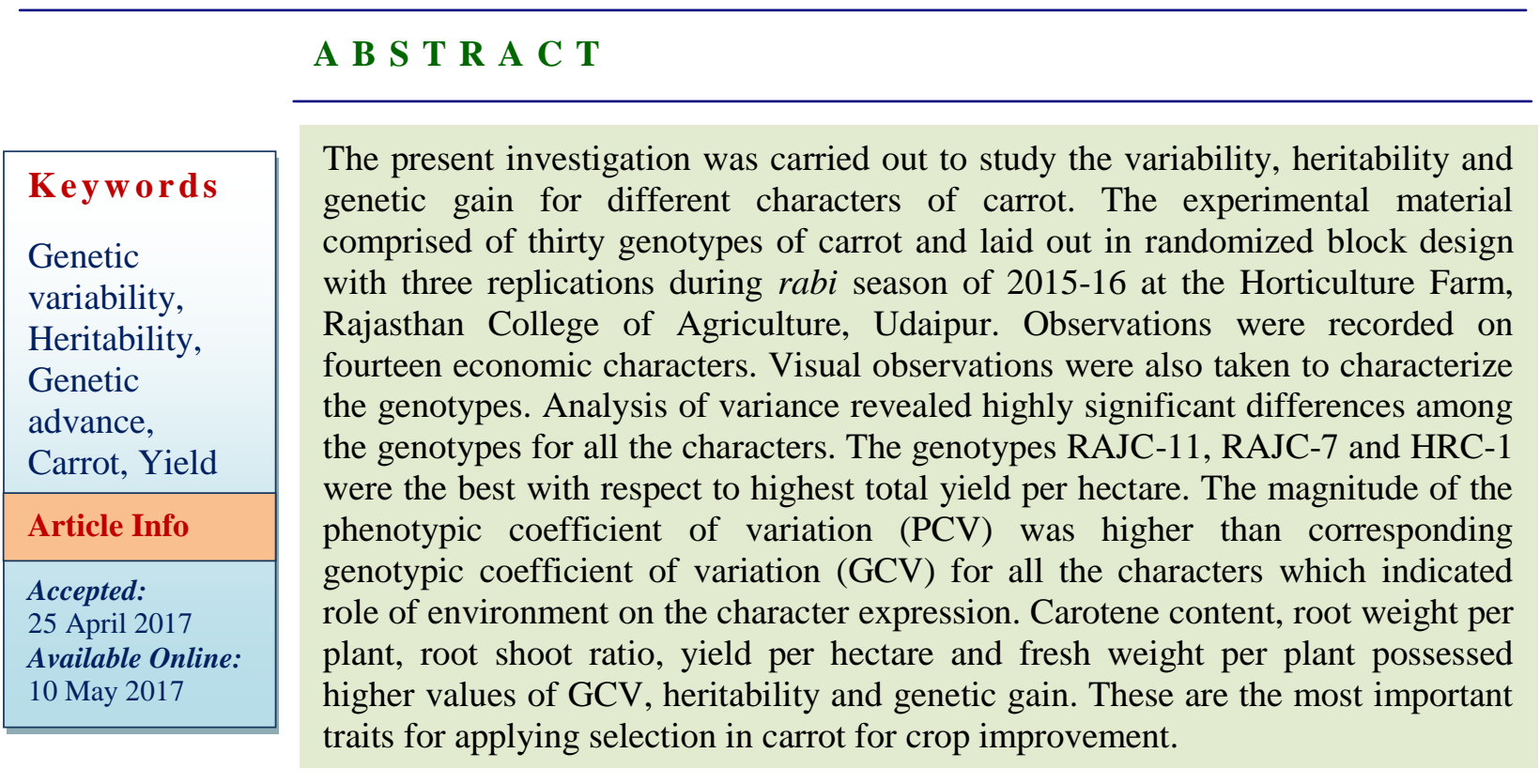

\section{Introduction}

Carrot (Daucus carota var. sativa L.), a member of family Apiaceae, is one of the most important vegetables in the world. It occupies the pride place due to its delicious taste, flavor and nutritive value. Carrot is grown throughout the world and is native of Afghanistan (Banga, 1976) and is an important root crop grown in India. Carrot is an important root vegetable used for salad, cooked vegetable, processed product like canned pickles, preserves, gajar halwa, carrot powders and kanji (an appetizing drink) etc.
Major carrot growing areas in the world are China, Russia, United State of America, Uzbekistan, Poland, Ukraine, United Kingdom, France and Japan etc. In India during 2014-15, 1092.63 thousand tons of carrot was produced from 68.05 thousand hectare area. Major carrot growing states in India are Haryana, Tamil Nadu, Punjab, Karnataka, Uttar Pradesh and Assam (Saxena et al., 2016). One of the limiting factors for low productivity of any crop is lack of superior genotypes or improved cultivars. So, 
there is need for development of new varieties and hybrids with high productivity. The critical assessment of nature and magnitude of variability in the germplasm stock is one of the important pre-requisites for formulating effective breeding programme (Janaki et al., 2015). Improvement in any crop is proportional to the magnitude of its genetic variability present in germplasm. Greater the variability in a population, there are the greater chances for effective selection for desirable types (Vavilov, 1951). Phenotypic and genotypic coefficients of variation are useful in detecting amounts of variability present in germplasm. Heritability is the portion of phenotypic variation which is transmitted from parent to progeny. Higher the heritable variation, greater will be the possibility of fixing the characters by selection. Hence, heritability studies are of foremost importance to judge whether the observed variation for a particular character is due to genotype or due to environment. Heritability estimates may not provide clear predictability of the breeding value. Thus, estimation of heritability accompanied with genetic advance is generally more useful than heritability alone in prediction of the resultant effect for selecting the best individuals (Johnson et al., 1955). Keeping in view of this, an attempt was made to study the genetic variability, heritabilty and genetic advance for various economic characters in 30 genotypes of carrot.

\section{Materials and Methods}

The present investigation was carried out at Horticulture Farm, Department of Horticulture, Rajasthan College of Agriculture, Maharana Pratap University of Agriculture and Technology, Udaipur during rabi season of 2015-2016. The region falls under Agro-Climatic Zone IV A "Sub-humid Southern Plain and Aravalli Hills of Rajasthan" at an altitude of 582.17 meter above mean sea level, at $24^{\circ} 35^{\prime} \mathrm{N}$ latitude and $74^{\circ} 42^{\prime}$ E longitude. Experimental material consisted of thirty germplasm lines collected from different locations of Rajasthan, Madhya Pradesh, Haryana and Punjab. The experiment was laid out in randomized block design (RBD) with three replications. For a healthy crop, appropriate standard and uniform cultural practices like thinning, weeding, hoeing, timely irrigations and plant protection measures were adopted. Observations were recorded on fourteen economic characters $v i z$. , days to germination, plant height (30 and 60 DAS), leaf length $(\mathrm{cm})$, number of leaves per plant, fresh weight per plant $(\mathrm{g})$, root length $(\mathrm{cm})$, root diameter $(\mathrm{cm})$, flesh thickness $(\mathrm{cm})$, root weight $(\mathrm{g})$, root : shoot ratio, TSS $\left({ }^{\circ} \mathrm{B}\right)$, total sugar content $(\%)$ and carotene content $(\mu \mathrm{g} / 100 \mathrm{~g})$. Total Sugar was estimated by using Anthrone reagent method (Dubois et al., 1951). Total carotene content was expressed as $\mu \mathrm{g} / \mathrm{l00 \textrm {g }}$ fresh weight of carrot (Thimmiah, 1999). Visual observations were also taken on type of distal end, presence or absence of forking and root colour. Analysis of variance was calculated according to the method suggested by Panse and Sukhatme (1985). The phenotypic and genotypic coefficients of variation (PCV and GCV) were estimated as per Burton and DeVane (1953). Heritability in the broad sense and genetic advance (in terms of percentage of mean) were computed according to Allard (1960) and Johnson et al., (1955), respectively.

\section{Results and Discussion}

Analysis of variance revealed highly significant differences among the genotypes for all the characters which indicated that experimental material possessed good deal of variability for improvement. Based on the mean performance, the genotypes RAJC-11 (310.80 q/ha), RAJC-7 (310.80 q/ha), HRC-1 (299.70 q/ha), RAJC-5 (289.27 q/ha) and 
MPC-7 (288.60 q/ha) were the best with respect to highest total yield per hectare. Highest TSS content was noted in HRC-2 $\left(10.10{ }^{\circ} \mathrm{B}\right)$ while highest total sugar content was observed in PBC-7 (4.30 \%) and MPC-6 $(4.30 \%)$. The genotype RAJC-5 was found with highest carotene content $(5.04 \mu \mathrm{g} / 100 \mathrm{~g})$ (Table 1). Visual observations (type of distal end, presence or absence of forking and root colour) taken during the experiment have been presented in table 2. The extent of variability present in the carrot genotypes was measured in terms of range, phenotypic coefficient of variation (PCV), genotypic coefficient of variation (GCV), heritability (broad sense) and expected genetic advance as per cent of mean (Table 3). High range was observed for all the character under study.

Table.2 Visual observations of different genotypes of carrot

\begin{tabular}{|c|c|c|c|c|}
\hline S. No. & Genotype & Distal end & Forking & Root colour \\
\hline 1. & HRC-1 & Acute & Absent & Red \\
\hline 2. & MPC-2 & Acute & Absent & Red \\
\hline 3. & HRC-2 & Acute & Absent & Red \\
\hline 4. & RAJC-3 & Acute & Absent & Light red \\
\hline 5. & RAJC-5 & Acute & Present & Black \\
\hline 6. & RAJC-8 & Acute & Absent & Red \\
\hline 7. & RAJC-7 & Acute & Present & Red \\
\hline 8. & PBC-1 & Acute & Present & Red \\
\hline 9. & RAJC-1 & Acute & Absent & Red \\
\hline 10. & RAJC-11 & Acute & Absent & Dark red \\
\hline 11. & PBC-3 & Acute & Present & Red \\
\hline 12. & RAJC-4 & Blunt & Absent & Red \\
\hline 13. & RAJC-6 & Acute & Absent & Red \\
\hline 14. & MPC-3 & Acute & Present & Red \\
\hline 15. & HRC-3 & Acute & Absent & Dark red \\
\hline 16. & PBC-2 & Blunt & Present & Red \\
\hline 17. & MPC-1 & Acute & Absent & Dark red \\
\hline 18. & PBC-6 & Blunt & Absent & Red \\
\hline 19. & MPC-7 & Blunt & Absent & Red \\
\hline 20. & RAJC-9 & Acute & Present & Dark red \\
\hline 21. & PBC-4 & Acute & Present & Dark red \\
\hline 22. & HRC-4 & Blunt & Absent & Dark red \\
\hline 23. & MPC-4 & Acute & Absent & Red \\
\hline 24. & PBC-5 & Acute & Present & Light red \\
\hline 25. & PBC-7 & Acute & Present & Red \\
\hline 26. & MPC-5 & Acute & Absent & Red \\
\hline 27. & HRC-5 & Acute & Present & Red \\
\hline 28. & RAJC-2 & Acute & Absent & Red \\
\hline 29. & RAJC-10 & Acute & Absent & Dark red \\
\hline 30. & MPC-6 & Acute & Absent & Red \\
\hline
\end{tabular}


Table.1 Mean performance of genotype for different characters studied in carrot

\begin{tabular}{|c|c|c|c|c|c|c|c|c|c|c|c|c|c|c|c|c|}
\hline S. No. & Genotypes & $\begin{array}{l}\text { Days to } \\
\text { germination }\end{array}$ & $\begin{array}{c}\text { Plant } \\
\text { height } \\
(30 \\
\text { DAS })\end{array}$ & $\begin{array}{c}\text { Plant } \\
\text { height } \\
(60 \\
\text { DAS })\end{array}$ & $\begin{array}{c}\text { Leaf } \\
\text { length } \\
(\mathrm{cm})\end{array}$ & $\begin{array}{l}\text { Number } \\
\text { of leaves } \\
\text { per plant }\end{array}$ & $\begin{array}{c}\text { Fresh } \\
\text { weight per } \\
\text { plant } \\
(\mathrm{g})\end{array}$ & $\begin{array}{l}\text { Root } \\
\text { length } \\
\text { (cm) }\end{array}$ & $\begin{array}{c}\text { Root } \\
\text { diameter } \\
(\mathbf{c m})\end{array}$ & $\begin{array}{c}\text { Flesh } \\
\text { thickness } \\
\text { (cm) }\end{array}$ & $\begin{array}{c}\text { Root } \\
\text { weight } \\
\text { per plant } \\
\text { (g) }\end{array}$ & $\begin{array}{c}\text { Root } \\
\text { shoot : } \\
\text { ratio }\end{array}$ & $\begin{array}{l}\text { Yield } \\
\text { (q/ha) }\end{array}$ & $\begin{array}{l}\text { TSS } \\
\left({ }^{0} \mathbf{B}\right)\end{array}$ & $\begin{array}{c}\text { Total } \\
\text { sugar } \\
\text { content } \\
(\%) \\
\end{array}$ & $\begin{array}{c}\text { Carotene } \\
\text { content } \\
(\mathrm{mg} / \mathbf{1 0 0 g})\end{array}$ \\
\hline 1 & HRC-1 & 10.67 & 24.20 & 35.40 & 46.00 & 11.02 & 231.26 & 30.66 & 3.31 & 0.70 & 135.00 & 1.40 & 299.70 & 9.20 & 3.30 & 2.98 \\
\hline 2 & MPC-2 & 11.67 & 22.60 & 36.80 & 51.68 & 12.01 & 205.01 & 30.67 & 3.60 & 1.00 & 115.00 & 1.29 & 255.01 & 8.60 & 3.20 & 2.63 \\
\hline 3 & HRC-2 & 11.33 & 22.00 & 29.80 & 48.00 & 6.94 & 166.94 & 29.67 & 3.44 & 1.42 & 118.00 & 2.43 & 261.29 & 10.10 & 3.60 & 1.76 \\
\hline 4 & RAJC-3 & 11.67 & 21.40 & 31.20 & 34.67 & 10.02 & 58.34 & 29.67 & 2.64 & 0.80 & 40.00 & 2.18 & 88.80 & 7.00 & 3.80 & 3.35 \\
\hline 5 & RAJC-5 & 12.67 & 19.13 & 40.60 & 50.34 & 14.01 & 252.50 & 36.33 & 4.10 & 1.60 & 130.00 & 1.06 & 289.27 & 7.40 & 3.90 & 5.04 \\
\hline 6 & RAJC-8 & 13.33 & 17.20 & 33.40 & 44.34 & 12.02 & 140.01 & 31.67 & 3.40 & 1.00 & 90.00 & 1.80 & 199.80 & 6.90 & 3.40 & 3.55 \\
\hline 7 & RAJC-7 & 10.33 & 21.07 & 41.40 & 46.34 & 11.01 & 200.00 & 29.67 & 4.07 & 1.20 & 140.00 & 2.33 & 310.80 & 6.10 & 2.80 & 2.32 \\
\hline 8 & PBC-1 & 12.67 & 19.60 & 32.80 & 36.34 & 12.01 & 83.34 & 32.00 & 2.69 & 0.80 & 42.00 & 1.01 & 93.24 & 5.20 & 3.10 & 0.89 \\
\hline 9 & RAJC-1 & 12.67 & 14.20 & 30.60 & 38.34 & 10.02 & 175.01 & 29.00 & 4.50 & 1.20 & 115.00 & 1.92 & 255.30 & 6.10 & 4.20 & 1.01 \\
\hline 10 & RAJC-11 & 12.00 & 14.60 & 33.20 & 46.68 & 13.01 & 212.51 & 32.00 & 4.50 & 1.50 & 140.00 & 1.93 & 310.80 & 7.20 & 3.30 & 1.64 \\
\hline 11 & PBC-3 & 13.67 & 16.00 & 34.20 & 35.34 & 6.01 & 165.01 & 28.33 & 3.76 & 1.20 & 105.00 & 1.75 & 233.10 & 7.40 & 2.30 & 0.72 \\
\hline 12 & RAJC-4 & 10.00 & 22.00 & 27.20 & 40.66 & 9.02 & 100.00 & 31.00 & 2.79 & 1.00 & 55.00 & 1.22 & 122.10 & 7.20 & 2.20 & 2.18 \\
\hline 13 & RAJC-6 & 8.67 & 22.20 & 33.74 & 54.00 & 11.01 & 150.01 & 30.67 & 3.30 & 0.50 & 95.00 & 1.74 & 210.90 & 8.00 & 2.90 & 1.75 \\
\hline 14 & MPC-3 & 8.00 & 24.20 & 32.59 & 52.00 & 9.02 & 110.01 & 28.00 & 2.67 & 0.80 & 74.13 & 1.72 & 155.40 & 7.40 & 3.60 & 1.07 \\
\hline 15 & HRC-3 & 13.33 & 24.00 & 27.60 & 46.68 & 10.01 & 121.43 & 27.00 & 3.90 & 1.50 & 80.00 & 1.93 & 177.60 & 7.40 & 4.10 & 1.37 \\
\hline 16 & PBC-2 & 11.67 & 20.00 & 27.00 & 42.34 & 11.01 & 156.27 & 31.33 & 3.96 & 1.59 & 120.00 & 3.31 & 266.40 & 7.50 & 4.00 & 1.53 \\
\hline 17 & MPC-1 & 9.67 & 20.40 & 28.60 & 41.31 & 13.01 & 140.00 & 29.00 & 2.10 & 0.99 & 100.00 & 2.50 & 222.00 & 6.90 & 3.30 & 1.71 \\
\hline 18 & PBC-6 & 8.67 & 24.06 & 27.00 & 42.68 & 13.01 & 181.25 & 20.00 & 2.93 & 1.00 & 110.00 & 1.54 & 244.20 & 6.20 & 3.60 & 0.81 \\
\hline 19 & MPC-7 & 10.67 & 22.60 & 29.60 & 37.68 & 11.01 & 175.01 & 29.33 & 4.17 & 1.30 & 130.00 & 2.89 & 288.60 & 9.40 & 3.90 & 0.78 \\
\hline 20 & RAJC-9 & 8.00 & 24.13 & 27.40 & 54.00 & 13.00 & 100.01 & 25.00 & 2.97 & 1.20 & 65.00 & 1.86 & 210.97 & 5.90 & 3.70 & 0.69 \\
\hline 21 & PBC-4 & 8.00 & 27.80 & 30.20 & 44.34 & 12.01 & 125.00 & 31.67 & 3.63 & 1.00 & 80.00 & 1.78 & 177.93 & 9.20 & 2.80 & 0.68 \\
\hline 22 & HRC-4 & 8.00 & 23.40 & 27.40 & 41.20 & 13.00 & 99.34 & 32.00 & 3.20 & 1.10 & 55.00 & 1.22 & 122.10 & 8.60 & 3.60 & 1.45 \\
\hline 23 & MPC-4 & 10.33 & 22.26 & 29.00 & 42.70 & 13.00 & 120.01 & 27.67 & 2.97 & 1.20 & 74.32 & 1.63 & 166.50 & 7.40 & 3.40 & 1.58 \\
\hline 24 & PBC-5 & 11.67 & 22.00 & 25.80 & 38.34 & 7.01 & 134.33 & 28.67 & 3.30 & 0.90 & 101.33 & 3.08 & 226.44 & 8.00 & 3.20 & 1.75 \\
\hline 25 & PBC-7 & 8.67 & 23.00 & 31.00 & 42.68 & 12.01 & 140.01 & 26.33 & 4.03 & 1.00 & 101.00 & 2.50 & 222.00 & 6.60 & 4.30 & 1.38 \\
\hline 26 & MPC-5 & 13.00 & 23.07 & 28.40 & 43.68 & 13.00 & 100.01 & 26.00 & 3.23 & 1.20 & 51.00 & 1.04 & 113.22 & 9.00 & 4.10 & 2.11 \\
\hline 27 & HRC-5 & 13.00 & 22.93 & 27.00 & 39.00 & 10.01 & 108.34 & 29.33 & 3.67 & 1.00 & 75.00 & 2.25 & 166.50 & 7.40 & 4.20 & 2.40 \\
\hline 28 & RAJC-2 & 10.67 & 25.20 & 28.80 & 40.68 & 9.01 & 156.25 & 29.67 & 4.07 & 1.60 & 115.00 & 2.79 & 255.30 & 8.00 & 2.90 & 3.30 \\
\hline 29 & RAJC-10 & 8.00 & 24.40 & 29.74 & 41.00 & 12.01 & 110.33 & 28.66 & 4.03 & 1.00 & 70.00 & 1.75 & 155.40 & 6.60 & 2.70 & 3.38 \\
\hline \multirow[t]{5}{*}{30} & MPC-6 & 7.67 & 22.93 & 28.68 & 55.34 & 14.00 & 87.51 & 32.00 & 3.90 & 0.90 & 42.00 & 0.92 & 93.24 & 7.40 & 4.30 & 3.20 \\
\hline & GM & 10.68 & 21.75 & 30.87 & 43.95 & 11.11 & 143.50 & 29.43 & 3.49 & 1.11 & 92.13 & 1.89 & 206.46 & 7.51 & 3.46 & 1.97 \\
\hline & SEm \pm & 0.46 & 0.82 & 0.96 & 1.44 & 0.37 & 6.92 & 0.96 & 0.12 & 0.04 & 3.73 & 0.07 & 10.50 & 0.08 & 0.05 & 0.03 \\
\hline & $\mathrm{CD}(5 \%)$ & 1.31 & 2.33 & 2.73 & 4.07 & 1.05 & 19.60 & 2.73 & 0.34 & 0.11 & 10.55 & 0.20 & 29.73 & 0.23 & 0.13 & 0.07 \\
\hline & $\mathrm{CV}$ & 7.50 & 6.56 & 5.41 & 5.66 & 5.79 & 8.36 & 5.67 & 5.97 & 6.02 & 7.01 & 6.57 & 8.81 & 1.86 & 2.34 & 2.23 \\
\hline
\end{tabular}


Table.3 GCV, PCV, heritability, genetic advance and genetic gain for different characters studied in carrot

\begin{tabular}{|c|c|c|c|c|c|c|c|}
\hline S.No. & Characters & GCV $(\%)$ & $\operatorname{PCV}(\%)$ & $\operatorname{ECV}(\%)$ & $\mathbf{h}^{2}(\%)$ & GA & GG $(\%)$ \\
\hline \multirow[t]{3}{*}{2.} & Plant height & & & & & & \\
\hline & $\begin{array}{l}\text { I. } 30 \text { Days after } \\
\text { sowing }\end{array}$ & 13.60 & 15.09 & 6.56 & 81.14 & 5.49 & 25.23 \\
\hline & $\begin{array}{l}\text { II. } 60 \text { Days after } \\
\text { sowing }\end{array}$ & 12.32 & 13.46 & 5.41 & 83.85 & 7.17 & 23.24 \\
\hline 4. & Number of leaves per plant & 18.39 & 19.28 & 5.79 & 90.97 & 4.01 & 36.13 \\
\hline 5. & Fresh weight per plant (g) & 32.04 & 33.11 & 8.36 & 93.63 & 91.65 & 63.87 \\
\hline 6. & Root length (cm) & 9.18 & 10.79 & 5.67 & 72.39 & 4.74 & 16.09 \\
\hline 10. & Root shoot : ratio & 33.18 & 33.82 & 6.57 & 96.23 & 1.27 & 67.04 \\
\hline 11. & Yield (q/ha) & 32.45 & 33.62 & 8.81 & 93.14 & 133.19 & 64.51 \\
\hline 12. & TSS $\left({ }^{0} \mathbf{B}\right)$ & 15.17 & 15.29 & 1.86 & 98.52 & 2.33 & 31.02 \\
\hline 13. & Total sugar content $(\%)$ & 16.61 & 16.77 & 2.34 & 98.05 & 1.17 & 33.87 \\
\hline 14. & $\begin{array}{l}\text { Carotene content } \\
(\mathrm{mg} \text { g/100gm })\end{array}$ & 54.29 & 54.33 & 2.23 & 99.83 & 2.20 & 111.73 \\
\hline
\end{tabular}

* GCV - genotypic coefficient of variation, PCV - phenotypic coefficient of variation, $\mathrm{h}^{2}$ - heritability in broad sense, GA - genetic advance and GG- genetic gain 
The magnitude of the phenotypic coefficient of variation was higher than corresponding genotypic coefficient of variation for all the characters which indicated predominant role of environment on the character expression. This is in line with the results obtained by Tewatia and Dudi (1999), Yadav et al., (2009) and Amin and Singla (2010). The estimates of PCV and GCV were high for carotene content $(\mathrm{GCV}=$ $54.29 \%, \mathrm{PCV}=54.33 \%$ ), root weight per plant $(\mathrm{GCV}=33.29 \%, \mathrm{PCV}=34.02 \%)$, root: shoot ratio $(\mathrm{GCV}=33.18 \%, \mathrm{PCV}=33.82 \%)$, yield per hectare $(\mathrm{GCV}=32.45 \%, \mathrm{PCV}=33.62 \%)$ and fresh weight per plant $(\mathrm{GCV}=32.04 \%$, PCV $=33.11 \%$ ). High GCV and PCV estimates for total yield per hectare were also observed by Amin and Singla (2010). Similar to present study, Jain et al., (2010) also observed high GCV and PCV for root weight while Priya and Santhi (2015) observed high GCV and PCV for carotene content in carrot. Selection is always favoured when a major proportion of a large amount of phenotypic variability is due to heritable variation. Heritability is useful in predicting the expected progress to be achieved through selection (Johnson et al., 1955; Allard, 1960). In the present study, high heritability was observed for all the characters except root length. The highest broad sense heritability was noticed for carotene content $(99.83 \%)$ followed by total sugar content (98.05\%), TSS (98.52 $\%$ ), root: shoot ratio (96.23\%), root weight per plant $(95.76 \%)$, fresh weight per plant $(93.63$ $\%)$ and yield per hectare $(93.14 \%)$. High heritability in broad sense indicated that large proportion of phenotypic variance was attributable to the genotypic variance and that these character differences among the genotypes were real and these traits were less influenced by the environment. High heritability in carrot was reported by Amin and Single (2010) for fresh weight/plant, root weight and total yield, by Jain et al., (2010) for fresh weight per plant, root weight and root length, by Yadav et al., (2009) for TSS and by Priya and Santhi (2015) for root carotene content and root weight. Kaur et al., (2009) also observed high heritability for TSS and carotene content in carrot.
The phenotypic superiority of selected plants or families over the original population is not solely due to their genotype superiority. It may be due to favorable environmental factors and so heritability estimates alone are not reliable. Genetic advance in some cases gives good idea for the actual position. Improvement in the mean genotypic value of the selected families over base population is known as genetic advance. Genetic advance depends upon heritability of the character under selection, genetic variability of genotypes and intensity of selection. Johnson et al., (1955) stressed that for estimating the real effects of selection, heritability alone is not sufficient and genetic advance along with heritability is more useful. High genetic advance as per cent of mean (genetic gain) was observed for carotene content $(111.73 \%)$ followed by root weight $(67.10 \%)$, root: shoot ratio $(67.04 \%)$, yield per hectare $(64.51 \%)$ and fresh weight per plant (63.87 \%). Similarly, high genetic gain was observed by Jain et al., (2010) for fresh weight per plant, root weight and yield per hectare and by Amin and Singla (2010) for yield per hectare. For carotene content high genetic gain was noticed by Priya and Santhi (2015) while for root: shoot ratio high genetic gain was noted by Thakur and Jamwal (2015).

High value of heritability associated with high genetic advance as per cent of mean were observed for carotene content, root: shoot ratio, root weight per plant, fresh weight per plant and yield per hectare. This is attributed to the additive gene action. So these characters can be easily improved by selection methods (Jain et al., 2010; Priya and Santhi, 2015). Flesh thickness, number of leaves per plant, days to germination, root diameter, total sugar content and TSS content accounted for the higher heritability along with moderate genetic gain. So these characters can be partially improved by selection methods. High or moderate heritability coupled with low genetic gain was found for root length, leaf length and plant height. This indicates the predominance of nonadditive variance in the expression of these characters. So these characters offer little scope 
for selection (Yadav et al., 2009; Priya and Santhi, 2015).

In the present investigation, carotene content, root weight per plant, root: shoot ratio, yield per hectare and fresh weight per plant possessed higher values of GCV, heritability and genetic gain. Selection for these characters would be effective for bringing improvement in carrot.

\section{References}

Allard, R.W. 1960. Principles of Plant Breeding. J. Wiley and Sons, London. pp. 83-88.

Amin, A. and Singla, J. 2010. Genetic variability, heritability and genetic advance studies in carrot (Daucus carota var. sativa L.). Electronic J. Plant Breed., 1(6): 1504-1508.

Banga, O. 1976. Carrot (Daucus carota L.) (Umbelliferae). In: Simmond, N. W. (ed.) Evolution of Crop Plants. Longman Inc; NewYork, U.S.A. 291-293.

Burton, G.W. and Devane, E.H. 1953. Estimating the heritability in tall fescue (Festuca arundinancea) from replicated clonal material. Agronomy J., 45: 478-481.

Dubois, M., Gilles, K., Hamitton, J.K., Robbers, P.A. and Smith, F. 1951. A colorometric method for determination of sugar. Nature, 16: 167.

Jain, Y.P., Dod. V.N., Nagare, P.K. and Kale, V.S. 2010. Genetic variability in carrot (Daucus carrota L.). The Asian J. Hort., 5(2): 514-516.

Janaki, M., Naidu, L.N., Ramana, C.V. and Rao, M.P. 2015. Assessment of genetic variability, heritability and genetic advance for quantitative traits in chilli (Capsicum annuum L.). The Bioscan, 10(2): 729-733.

Johnson, H.W., Robinson, H.F. and Comstock, R.E. 1955. Estimates of genetic and environmental variability in soyabean. Agronomy J., 47: 314-318.

Kaur, P., Cheema, D.S. and Chawla, N. 2009. Genetic variability, heritability and genetic advance for quality traits in carrot (Daucus carota L.). Veg. Sci., 36(2): 235-236.

Kumar, A., Pal, A.K. and Kumar, S. 2011. Genetic variability, correlation and path analysis in Asiatic carrot. Indian J. Hort., 68(3): 433-437.

Panse, V.G. and Sukhatme, P.V. 1985. Staistical Methods for Agricultural Workers, ICAR, New Delhi.

Priya, P.A. and Santhi, V.P. 2015. Variability, character association and path analysis for yield and yield attributes in carrot (Daucus carota L.). Electronic J. Plant Breed., 6(3): 861-865.

Sexena, M., Bhattacharya, S., Malhotra, S.K. 2016. Horticultural statistics at a glance. Oxford University Press, New Delhi. pp. 199-280.

Tewatia, A.S. and Dudi, B.S. 1999. Genetic variability and heritability studies in carrot (Daucus carota L.). Annals Agri Bio Res., 4: 213-214.

Thakur, N. and Jamwal, R.S. 2015. Genetic variability study of European carrot (Daucus carota L.) genotypes. Annals Agri Bio Res., 20(1): 40-42.

Thimmiah, S.R. 1999. Estimation of carotene content. Standard method of biochemical analysis. Kalyani publisher, New Delhi. pp. 304-305.

Vavilov, N.I. 1951. Origin, variation, immunity and breeding of cultivated plants. Chronol. Bot., 13: 4-364.

Yadav, M., Tirkey, S., Singh, D., Chaudhary, R., Roshan, R. and Pebam, N. 2009. Genetic variability, correlation coefficient and path analysis in carrot. Indian J. Hort., 66(3): 315-318.

\section{How to cite this article:}

Suresh Kumar Teli, R. A. Kaushik, K. D. Ameta, Vikram Kumar Kapuriya, Dalulal Mali and Lokesh Kumar Teli. 2017. Genetic Variability, Heritability and Genetic Advance In Carrot (Daucus carota Var. Sativa L.). Int.J.Curr.Microbiol.App.Sci. 6(5): 2336-2342. doi: https://doi.org/10.20546/ijcmas.2017.605.261 